\title{
Innovation policy as a basis for sustainable development of industrial regions
}

\author{
Mikhail Pestunov ${ }^{1, *}$ and Svetlana Pestunova ${ }^{1}$ \\ ${ }^{1}$ Chelyabinsk State University, 129, Br.Kashirinykh str., 454001, Chelyabinsk, Russia
}

\begin{abstract}
The purpose of the study is to develop approaches to the development of regional innovation policy, which will allow to create a more effective trajectory for the implementation of the innovation paradigm of industrial regions of the Russian Federation, taking into account the specificity of their scientific, engineering, manufacturing and innovative potentials. The article defines the role of innovation policy, which serves as the foundation for sustainable development of the industrial region. The article presents the analysis of innovation activity in the region. Paper develops the models of static and dynamic reproduction of intellectual capital. Authors used them to design a mechanism for incorporating the results of intellectual activity into an economic turnover. Authors examined the efficiency of the regional economy, its economic growth, as well as sustainable development of the industrial region. Its economic activity is determined by the development of the innovation policy of the region, which identifies the investment priorities in preference of intangible assets over tangible ones.
\end{abstract}

\section{Introduction}

The main trends of economic development are manifested in the increasing role of the results of intellectual activity, and the integration of objects of intellectual property in the economic turnover, which serve as a new basis of the technical and economic paradigm [1].

The efficiency of the regional economy, economic growth, sustainability of the development of vertically integrated systems and territorial complexes, as well as foreign economic activity is largely determined by the regional innovation policy based on the innovative approach. On the one hand, innovation policy reflects the level of development of the regional economy and its competitiveness, and on the other hand, it shows the level of economic security of the region [2].

According to the authors [3], one of the reasons for the poor efficiency of the current innovation policy in the Russian Federation is its abstract nature, and its detachment from the problems of social and economic development, as well as from the state and specific features of the innovation potential of various regions, and their demand for innovative transformations.

The development of innovation policy is one of the major requirements for achieving high and sustained rates of economic growth and technological development, thus

\footnotetext{
*Corresponding author: pestynov_ma@mail.ru
} 
contributing to the economic security of the region and the country as a whole. The development of innovation policy and its practical implementation is seen as a strategic resource to improve sustainability and, consequently, the competitiveness of the economy of the region. Innovative activity is characterized by relationships and flows of knowledge between the various actors and institutions. It can be seen as a process that occurs in a system of interrelated entities. The effectiveness of the regional system may depend on both the availability of entities and the intensity of interaction and corresponding flows of knowledge [4].

\section{Materials and methods}

At this point, the Russian Federation is practically gone from the high-technology market. For example, in terms of the volume of high-technology exports, Russia falls behind the United States by almost 16 times, and behind China by 57 times [5]. Investment processes develop with the priority of costs in low-tech and medium-tech industries. About $2.4 \%$ of expenses on technological innovations are invested in the machine-building industry of the Russian Federation as a whole, and only $1.7 \%$ of the output of innovative products.

Researchers [6] point out that innovation abilities and the level of innovation development of the industrial region depend on the strong scientific and production potentials, as well as innovation activity.

The use of innovative potential in combination with available resources and factors is typical for the world's leading countries. The creativity of researchers has a special role in the system of these resources. It is implemented not only in high-quality scientific works but also in innovative activities. The nature and intensity of innovative activity in a particular industry are largely determined by the level of specialization. Inventive activity tends to be higher in territories that specialize in a particular industry [7, 8]. It is also important to highlight the existence of a negative correlation between regional diversification and the efficiency of innovative activity [9]. At the same time, innovations are not distributed equally. The number of registered inventions is greater in regions with a distinct industrial character. Research on the production activities of different companies does not give divergent results. According to a number of sources, there is a positive correlation between regional specialization and the probability that companies will introduce a new product, while the role of diversification is insignificant [10].

In one of the papers [11] authors mentioned the share of Russia in the number of papers indexed in the World of Science, which was only $2.28 \%$ in 2016.

Table 1. Number of published information on inventions, utility models, and industrial prototypes.

\begin{tabular}{|c|c|c|c|c|}
\hline Years & $\begin{array}{c}\text { Applications for } \\
\text { inventions }\end{array}$ & $\begin{array}{c}\text { Patents for } \\
\text { inventions }\end{array}$ & $\begin{array}{c}\text { Patents for utility } \\
\text { models }\end{array}$ & $\begin{array}{c}\text { Patents for } \\
\text { industrial } \\
\text { prototypes }\end{array}$ \\
\hline 2015 & 25573 & 34712 & 9014 & 5493 \\
\hline 2016 & 20283 & 33537 & 8876 & 4460 \\
\hline 2017 & 24961 & 34255 & 8774 & 5110 \\
\hline 2018 & 18734 & 35775 & 9868 & 6334 \\
\hline 2019 & 15897 & 34008 & 8848 & 5420 \\
\hline
\end{tabular}

The percentage of applications for inventions submitted by Russian scientists was $1.2 \%$ in 2015. This situation has not changed at the present time. The share of patents for inventions, utility models, and industrial prototypes granted in 2019 is presented in Table 2. 
Table 2. Dynamics of submission and consideration of applications for patents of the Russian Federation in 2015-2019

\begin{tabular}{|l|c|c|c|c|c|c|}
\hline \multicolumn{1}{|c|}{ Years } & $\mathbf{2 0 1 5}$ & $\mathbf{2 0 1 6}$ & $\mathbf{2 0 1 7}$ & $\mathbf{2 0 1 8}$ & $\mathbf{2 0 1 9}$ & $\begin{array}{c}\text { 2019 } \\
\text { (compared to } \\
\text { 2018 in \%) }\end{array}$ \\
\hline $\begin{array}{l}\text { Total number of } \\
\text { applications submitted to } \\
\text { the Federal Service for } \\
\begin{array}{l}\text { Intellectual Property } \\
\text { (Rospatent) }\end{array}\end{array}$ & 45517 & 41587 & 36454 & 37957 & 35511 & 93.56 \\
\hline Russian applicants & 29269 & 26795 & 22777 & 24926 & 23337 & 93.63 \\
\hline Foreign applicants & 16248 & 14792 & 13677 & 13031 & 12174 & 93.42 \\
\hline
\end{tabular}

Table 2 illustrates that the number of submitted applications to Rospatent has decreased from 45517 applications in 2015 as compared to 35511 applications in 2019. This is evidence of a decrease in inventive activity in the country as a whole.

Table 3. Comparative analysis of applications for inventions by the Federal districts of the Russian Federation in 2019.

\begin{tabular}{|l|c|c|}
\hline $\begin{array}{c}\text { Federal District of the } \\
\text { Russian Federation }\end{array}$ & $\begin{array}{c}\text { Applications for } \\
\text { inventions } \\
\text { Number of submitted } \\
\text { applications }\end{array}$ & $\begin{array}{c}\text { \% of the total number of } \\
\text { applications }\end{array}$ \\
\hline Central & 10780 & 46.19 \\
\hline Northwestern & 3688 & 15.80 \\
\hline Volga Federal District & 3467 & 14.86 \\
\hline Siberian & 1934 & 8.29 \\
\hline Southern & 1502 & 6.44 \\
\hline Ural & $\mathbf{1 0 1 7}$ & $\mathbf{4 . 3 6}$ \\
\hline Far Eastern & 493 & 2.11 \\
\hline North Caucasian & 406 & 1.74 \\
\hline Undefined district & 50 & 0.21 \\
\hline Total: & 23337 & 100 \\
\hline
\end{tabular}

However, in comparison to 2015 , the number of granted patents decreased slightly from 34706 to 34008 in 2019. This indicates the level of the technical and economic significance of the inventions, as well as the level of novelty and the level of achieved results, remain unchanged. Comparative analysis of submitted applications by the federal districts of the Russian Federation in 2019 is presented in Table 4.

Table 4. Distribution of applications submitted by Russian applicants from the Ural Federal District in 2015 .

\begin{tabular}{|l|c|c|c|}
\hline \multirow{2}{*}{ Ural Federal District } & \multirow{2}{*}{ Total } & \multicolumn{2}{c|}{$\begin{array}{c}\text { Number of submitted } \\
\text { applications: }\end{array}$} \\
\cline { 3 - 4 } & & $\begin{array}{c}\text { by legal } \\
\text { entities }\end{array}$ & $\begin{array}{c}\text { by } \\
\text { private } \\
\text { entities }\end{array}$ \\
\hline Kurgan Oblast & & 37 & 19 \\
\hline Sverdlovsk Oblast & 56 & 409 & 117 \\
\hline Tyumen Oblast & 526 & 156 & 31 \\
\hline Khanty-Mansi Autonomous Okrug - Yugra & 187 & 23 & 15 \\
\hline Chelyabinsk Oblast & 38 & 210 & 99 \\
\hline Yamalo-Nenets Autonomous Okrug & 309 & 30 & 2 \\
\hline Total for the district: & 32 & 865 & 283 \\
\hline
\end{tabular}


The number of submitted applications characterizes the intensity of innovation activity in a particular region and is largely determined by the level of specialization. Inventive activity tends to be higher in those territories that have more developed scientific and production potential, and specialize in a particular industry.

Table 5. Distribution of submitted applications by Russian applicants from the Ural Federal District and its constituent entities in 2019.

\begin{tabular}{|l|c|c|c|}
\hline \multirow{2}{*}{ Ural Federal District } & \multirow{2}{*}{ Total } & \multicolumn{2}{c|}{$\begin{array}{c}\text { Number of submitted } \\
\text { applications: }\end{array}$} \\
\cline { 3 - 4 } & & $\begin{array}{c}\text { ay legal } \\
\text { entities }\end{array}$ & $\begin{array}{c}\text { by private } \\
\text { entities }\end{array}$ \\
\hline Kurgan Oblast & 48 & 26 & 22 \\
\hline Sverdlovsk Oblast & 513 & 377 & 136 \\
\hline Tyumen Oblast & 132 & 84 & 48 \\
\hline Khanty-Mansi Autonomous Okrug - Yugra & 48 & 21 & 27 \\
\hline Chelyabinsk Oblast & 242 & 160 & 82 \\
\hline Yamalo-Nenets Autonomous Okrug & 34 & 32 & 2 \\
\hline Total for the district: & 1017 & 700 & 317 \\
\hline
\end{tabular}

The number of submitted applications has not changed significantly in 2019. The dependence on the intensity of innovation activity in a particular region is also determined by the level of specialization. Comparative analysis of submitted applications for inventions by the federal districts of the Russian Federation in 2015 and 2019. Submitted applications for proposed inventions in 2015: Russian Federation - 45517, Ural Federal District - 1148. Submitted applications for proposed inventions in 2019: Russian Federation - 33511, Ural Federal District - 1017. The dynamics of submitted applications for proposed inventions characterizes the inventive activity in the country and the Ural Federal District.

Table 6. Distribution of patents granted to Russian applicants from the federal districts of the Russian Federation in 2015.

\begin{tabular}{|c|c|c|c|}
\hline \multirow{2}{*}{ Ural Federal District } & \multirow{2}{*}{ Total } & \multicolumn{2}{|c|}{$\begin{array}{c}\text { Number of } \\
\text { submitted } \\
\text { applications: }\end{array}$} \\
\hline & & $\begin{array}{c}\text { by legal } \\
\text { entities }\end{array}$ & $\begin{array}{c}\text { by } \\
\text { private } \\
\text { entities }\end{array}$ \\
\hline Kurgan Oblast & 40 & 32 & 8 \\
\hline Sverdlovsk Oblast & 509 & 395 & 114 \\
\hline Tyumen Oblast & 140 & 124 & 16 \\
\hline Khanty-Mansi Autonomous Okrug - Yugra & 37 & 26 & 11 \\
\hline Chelyabinsk Oblast & 355 & 298 & 57 \\
\hline Yamalo-Nenets Autonomous Okrug & 16 & 12 & 4 \\
\hline Total for the district: & 1097 & 887 & 210 \\
\hline
\end{tabular}

The number of patents granted to Russian applicants in the federal districts of the Russian Federation in 2015 is determined by the technical and economic importance of inventions and depends on the level of novelty, achieved results, and the potential for industrial application, which characterizes the commercial appeal. 
Table 7. Distribution of patents granted to Russian applicants from the Ural Federal District and its constituent entities in 2019.

\begin{tabular}{|l|c|c|c|}
\hline \multicolumn{1}{|c|}{ Ural } & Total & $\begin{array}{c}\text { Private } \\
\text { entities }\end{array}$ & $\begin{array}{c}\text { Legal } \\
\text { entities }\end{array}$ \\
\hline Kurgan Oblast & 46 & 25 & 21 \\
\hline Sverdlovsk Oblast & 481 & 388 & 93 \\
\hline Tyumen Oblast & 124 & 106 & 18 \\
\hline Khanty-Mansi Autonomous Okrug - Yugra & 44 & 21 & 23 \\
\hline Chelyabinsk Oblast & 276 & 199 & 77 \\
\hline Yamalo-Nenets Autonomous Okrug & 36 & 36 & 0 \\
\hline Total for the district: & 1007 & 775 & 232 \\
\hline
\end{tabular}

Comparative analysis of patents granted to Russian applicants in 2015 and 2019 (Tables 6-8) in the Russian Federation and the Ural Federal District. The number of granted patents in 2015: Russian Federation - 34706, Ural Federal District - 1097. The number of granted patents in 2019: Russian Federation - 34008, Ural Federal District - 1007. The dynamics of granted patents characterizes the level of the technical and economic significance of inventions. This also confirms the novelty, industrial application, and inventive step. The use of all types of available resources and factors is typical for the world's leading countries. The creativity of researchers has a special role in the system of these resources. It can be implemented not only in high-quality scientific works but also in innovative activities.

The analysis of Tables 1-8 revealed that the Ural Federal District holds sixth place (Table 4-5). In one of the papers [11, p. 291] authors mentioned the share of Russia in the number of papers indexed in the World of Science, which was only $2.28 \%$ in 2016 . The percentage of applications for inventions submitted by Russian scientists was $1.2 \%$ in 2015 . This situation has not changed at the present time. In 2019, the share of applications for patents, as well as granted patents for inventions, utility models and industrial prototypes from the Ural Federal District was 15897, 34008, 8848, and 5420 respectively (see Table $1)$.

When analysing social reproduction as a whole in terms of research methodology, researchers distinguish a number of approaches, including phase-based, evolutionary, levelbased, and structural-functional. According to the authors [11, p. 291], one of the leading components of the effectiveness of research activities in the framework of the reproduction of scientific and technological potential is primarily based on the intensification of innovative activity.

The studies of P. M. Romer present a methodology for studying the reproduction of intellectual capital in science and technology on the basis of the interaction of three sectors: scientific research, production of means of production, production of competitive products [12], macroeconomic scientific, and technological transformations, and technological modes.

One of the most significant characteristics of the region's ability to improve sustainability is the increasing role of the results of intellectual activity. In this case, authors understand intellectual activity as a state of innovation processes, which provides long-term reproduction of intellectual capital and its effective use as intangible assets of the enterprise [4].

We propose methodological approaches to the substantiation of priority trends in the development of regional innovation policy. The proposed methodology requires the procedures to be performed in a particular sequence. On the basis of the analysis and evaluation of the diffusion of the results of intellectual activity, the necessary growth rate of the region is estimated, the necessary need for innovations in the statistical and dynamic systems is calculated, the exhaustion of the effectiveness of intellectual property due to the 
growing rate of applications for the proposed inventions, utility models and industrial designs are assessed.

\section{Results}

Analysis of patent statistics allowed us to make a primary grouping of the subjects of the Russian Federation according to the level of innovation development. The regions ranked at the top of the tables for submission of applications and granting of patents are characterized by the greater degree of readiness to implement innovative transformations. The Ural Federal District is ranked sixth. The analysis allowed us to propose a hypothesis. In order to increase the level of innovation activity of the region, it is required to develop and implement an innovation policy. Industrial regions are able to make a leap in innovative development when combined with scientific and technical potential under the framework of innovation policy.

This paper presents the results of the primary assessment of the level of innovative development of Russian enterprises, which allowed us to identify the reasons for the decline in investment not only in tangible but primarily in intangible assets of the enterprise. Analysis of innovative short-sightedness, which is caused by short-term temporal orientation, allows us to understand the causes of inefficient financial behavior, the decline in investment in innovation at all levels of the economy, and the factors that ensure sustainable development of the enterprise. In practice, innovative short-sightedness is evident in the preference for investing in the reproduction of tangible assets over intangible ones.

Innovation policy creates a common social plan of action, which provides each subject of the market with a reference point for shaping expectations, i.e. forecast of the life cycle of the product with expected characteristics of competitiveness. Furthermore, innovation policy plays a coordinating role, because it makes the disparate expectations of market entities similar to each other. This can be seen in the generation of demand for a certain level of product quality from consumers and the generation of supply from manufacturers. Manufacturers must present a product with an acceptable balance between the set of technical and economic characteristics of the product and its price.

As a result of an effective innovation policy, there is a favorable environment for the reproduction of intangible assets, and a general tendency to opportunism is lowered. There are two reasons for this, namely the unification of ideas about the rules of conduct in the reproduction of intangible assets, as well as the need to protect the rights for the results of creative labor and their subsequent protection, i.e. the sanctions for violation of intellectual property rights.

Innovation policy clearly states and reduces the diversity of forms of development to two forms, which are different in their content and consequences. The first form of development is conditioned by an adaptation-type mechanism, which is similar to biological development, such as the mechanisms of natural selection, implemented through opportunistic behavior. The second form of development is innovative, which leads to the production of competitive goods. Innovative development is implemented within the framework of two strategies. The first strategy is to purchase exclusive rights to intellectual property (IP) under a license agreement. In this case, the transaction costs are reduced, while the level of risk is insignificant, and the required level of profitability is achieved as well. The second strategy is to implement an active innovation policy, when the company seeks to be the first to enter the market with a brand new product that is developed by the company itself, based on a new generation of IP. In general theoretical terms, this strategy implies a significant reorganization of the entire system of enterprise activity on the basis of transformation costs. 
The formal part of innovation policy is primarily about developing legislation that regulates contracts in the form of specification of IP rights and licensing agreements. With this approach, innovation policy is important to the extent that it determines the volume and structure of transaction costs.

We distinguish the following methodological sections within the innovation policy: management of reproduction of intangible assets in the operational process and strategic reproduction of intangible assets in the investment process. The methodology is a system of basic elements which regulate the process of development and implementation of managerial decisions in the sphere of reproduction of intangible assets.

Its main elements are the following processes:

1. Development of the information system which characterizes economic growth in the preceding period, and identification of economic growth and development in the future;

2.Development of the system and methods of planning the composition of intangible assets within the forecasted product life cycle;

3. Development of the system and methods of regulating, accounting, evaluation, and analysis, aimed at renovation of intangible assets by types, within the forecasted product life cycle, with regard to the exhaustion of IP efficiency.

It was found that the distribution of IP is influenced by competing and cooperating market entities: "innovators-creators", "imitators-licensees", "imitators-competitors" who develop alternative product variants, and "imitators-pirates". The assessment of the diffusion makes it possible to estimate the supply and demand for IP and to carry out the manageable reproduction of IP that is used in commercial circulation as intangible assets (IA). IP reproduction that is funded by one's own investments is called endogenous. IP reproduction that is covered by purchasing licenses is exogenous.

As a part of the development of innovation policy, we propose a method of reproduction of IA, which consists in the creation of sinking fund of IA, with regard to the exhaustion of the effectiveness of the implemented results of intellectual activity (RIA), which is determined by the diffusion of RIA used in the form of IA in the examined industry.

As a part of the development of innovation policy, reproduction methods were developed for stationary and dynamic systems of reproduction of intangible assets [20].

For the stationary system of reproduction of intangible assets (IA), when financing is provided at the expense of the enterprise's IA, the annual need for IA is calculated by the Formula 1:

$$
I_{i j}^{t}=b_{i j}^{t} Q_{i j}^{t} A \stackrel{t}{m}
$$

where $I^{t}{ }_{i j}$ is the annual requirement of the $j$-th enterprise in the $i$-th IA in the $t$-th year; $b_{i j}$ - is the partial coefficient of intellectual capacity; $Q^{t}{ }_{i j}$ is the production output volume of $j$-th enterprise on the basis of $i$-th IA in the $t$-th year, and $A m^{t} i j$ is the annual amortization rate of IA in \%;

For the dynamic system of reproduction of IA, when financing is provided at the expense of amortization, and at the expense of additional profits from the IP, the annual need in IP is calculated by the Formula 2:

$$
I_{i}^{t}{ }_{j} b_{i}^{t-1} Q_{i}^{t-1} A{ }_{i}^{t-1}+n b_{i}^{t} \Delta Q_{i}^{t} A{ }_{i}^{t}+\operatorname{Pm}_{i}^{t},
$$

where $I^{t}{ }_{i j}$ is the annual requirement of the $\mathrm{j}$-th enterprise in the $\mathrm{i}$-th IA in the $\mathrm{t}$-th year; $b_{i j}$ is the partial coefficient of intellectual capacity; $Q^{t}{ }_{i j}$ is the production output volume of $\mathrm{j}$-th enterprise on the basis of $\mathrm{i}$-th IA in the $\mathrm{t}$-th year; 
$A m^{t}{ }_{i j}$ is the annual amortization rate of IA; $\Delta Q^{t}$ is the gain in the production output; $\operatorname{Pr}^{t}{ }_{\mathrm{ij}}$ is the net profit from IP of $j$-th enterprise in the $t$-th year.

The procedures of reproduction of IA captured in the innovation policy establish the target structure of non-current assets, which changes over time due to the diffusion of RIA and the life cycle of innovation products.

In the process of managing the reproduction of intangible assets, it is possible to identify several areas of management activity of the enterprise, which are presented in Table 9. The proposed strategy for managing the sustainable development of the industrial region by means of innovation policy is based on the active involvement of the results of intellectual activity in the economic turnover and is grounded on the research of IP diffusion processes, their reproduction, with regard to the exhaustion of the efficiency and evaluation of the technical and economic significance of IP. The main stages of shaping IP management strategy in the investment process through program-targeted planning include: identification of the market environment in the form of a forecast of economic growth; goal setting and identification of objectives; search and selection of patent and market information;

With the help of the forecasting of the product life cycle within the proposed innovation policy, a system of competitiveness management is strategically built with the help of statistical methods of processing patent and market information.

Table 8. Areas of enterprise management activities for the management of IA reproduction as part of the innovation policy

\begin{tabular}{|c|c|c|}
\hline $\begin{array}{c}\text { Targeted } \\
\text { object }\end{array}$ & $\begin{array}{c}\text { Type of } \\
\text { transformation }\end{array}$ & Pattern of change \\
\hline $\begin{array}{l}\text { Production } \\
\text { output }\end{array}$ & $\begin{array}{l}\text { Ensuring the } \\
\text { competitiveness } \\
\text { of the product }\end{array}$ & $\begin{array}{l}\text { Development of a new product, as well as its } \\
\text { improvement and renewal on the basis of a new } \\
\text { generation of results of intellectual activity in accordance } \\
\text { with the market demands. They provide the required level } \\
\text { of competitiveness in accordance with new requirements } \\
\text { and standards, and technical specifications. }\end{array}$ \\
\hline $\begin{array}{l}\text { Technologi } \\
\text { cal process }\end{array}$ & $\begin{array}{l}\text { Improvement of } \\
\text { technological } \\
\text { processes }\end{array}$ & $\begin{array}{l}\text { A set of measures to improve the technical and economic } \\
\text { level of individual production facilities, workshops, and } \\
\text { sections at the expense of the involvement of } \\
\text { technological intellectual property objects in the } \\
\text { economic turnover aimed not only at modernizing } \\
\text { production, but also ensuring the rearrangement, } \\
\text { expansion of existing or construction of new facilities } \\
\text { based on a new generation of technological intangible } \\
\text { assets, which also includes the replacement of obsolete } \\
\text { and physically worn-out equipment with a new one on the } \\
\text { basis of a new generation of IP. }\end{array}$ \\
\hline 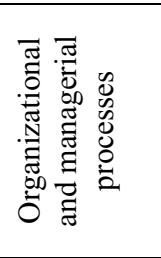 & Rearrangement & $\begin{array}{l}\text { A set of organizational and managerial innovations in the } \\
\text { form of know-how that lead to substantial changes, which } \\
\text { are characterized by rearrangement of the entire system of } \\
\text { organization and management of the organization in order } \\
\text { to achieve a beneficial synergy of changes in the structure } \\
\text { of capital, remove repetition of functions and reduce costs } \\
\text { while increasing production. }\end{array}$ \\
\hline
\end{tabular}




\begin{tabular}{|l|l|l|}
\hline $\begin{array}{l}\text { Organizational } \\
\text { restructuring }\end{array}$ & $\begin{array}{l}\text { The transformation of the structure of production and } \\
\text { management within the enterprise, which is based on } \\
\text { management intellectual property, typically in the mode } \\
\text { of intellectual property ownership. Organizational } \\
\text { restructuring includes changes in the organizational } \\
\text { structure and management system as a whole, and in } \\
\text { some cases, changes in organizational strategy. In } \\
\text { addition, there are changes to production structures, } \\
\text { including the replacement and modernization of } \\
\text { equipment, rationalization of the management hierarchy, } \\
\text { and systems for processing information. }\end{array}$ \\
\cline { 2 - 3 } & $\begin{array}{l}\text { Improvement of the overall efficiency of business } \\
\text { processes, including the re-design of business lines and } \\
\text { relationships within the organization while preserving the } \\
\text { existing links in the organizational structure. } \\
\text { Transformations in the field of methods and management } \\
\text { style of managers. This is also the expansion of the rights } \\
\text { of structural units and individual employees, the } \\
\text { incentivization of creative activity, and the delegation of } \\
\text { responsibility. }\end{array}$ \\
\hline
\end{tabular}

Within the same life cycle, product, and then technological and managerial IP are formed, which ensure the required level of competitiveness of the enterprise. At each stage of the life cycle, including development, growth, and maturity, it is required to consider each element of the life cycle trajectory and optimize its state by the criterion of ensuring the maximum income flow and the optimal balance of the structure of intangible assets, which ensure the competitiveness of the enterprise at a specific moment and in a strategic perspective.

The transition from production based on the previous IP generation to production based on the new IP generation, i.e. from one product life cycle to the next, should be made systematically after the exhaustion of the effectiveness of the corresponding type of IP product, technological, organizational, managerial.

\section{Conclusion}

The analysis of the state of innovation potential in the regions of the Russian Federation showed a significant difference between the territories on the level of their innovation development, as well as the isolation of regional innovation strategies from the overall strategies of social and economic and, in particular, industrial and technological development, which significantly reduces the opportunities for effective social and economic growth of the region.

We can distinguish three useful economic functions of innovation policy, namely, the development of a certain unified image of the future, increase in the general tendency to opportunism, and protection of contracts.

Regional innovation policy should be aimed at achieving the following objectives:

1. Determination of priorities of technological development of the region on the basis of available natural resources in the region, as well as the availability of industrial infrastructure and capabilities. These trends may not coincide with federal tendencies.

2. Creation of mutually beneficial conditions with the major owners and top managers with the established system of tools and recommendations of the innovation and technological policy.

3. Establishment of links between all elements of the regional innovation system to stimulate the development and transfer of new technologies. 
The analysis of the state of innovation activity in the industrial region, particularly in the Ural Federal District, showed the level of social and economic and, more particularly, scientific, technological, and industrial development of the region, which is largely determined by the level of innovation potential, as well as by the interaction of regional government and business structures. The analysis shows that innovation policy as a system of responsible relations between the government and businesses has the strongest impact on innovative development.

The causes of low competitiveness of industrial enterprises are a consequence of low innovation activity, caused by innovative short-sightedness and lack of innovation policy that is based on the market system of intellectual property management. In practice, the absence of innovation policy creates innovative short-sightedness, which, as we have mentioned, is expressed in preference of investing in modernization, re-equipment, or reproduction of tangible assets over intangible ones.

\section{References}

1. O.A. Romanova, Economy of the region 14(3), 806-819 (2018) doi 10.17059/2018-3-9

2. A.F. Sukhovey, I.M. Golova, Differentiation of strategies for innovative development of regions as a condition for improving the effectiveness of socio-economic policy in the Russian Federation

3. O.A. Romanova, The economy of the region 13(1), 276-289 (2017) doi 10.17059/2017-1-25

4. I.V. Grebenkin, The economy of the region 14(2), 600-611 (2018) doi 10.17059 / 2018-2-21

5. I.M., Golova A.F., Sukhovey N.L. Nikulina, The economy of the region 13(1), 308318 (2017) doi 10.17059 / 2017-1-27

6. I.M. Golova, A.F. Sukhovey, The economy of the region 14(3) (2018)

7. L. Greunz, Journal of Evolutionary Economics 14(5), 563-592 (2004) doi:10.1007/s00191-004-0234-8.

8. R. Paci, S. Usai, Geo Journal 49(4), 381-390 (1999) doi:10.1023/A:1007192313098

9. R. Andersson, J.M. Quigley, M. Wilhelmsson, Papers in Regional Science 84(3), 445464 (2005) doi:10.1111/j.1435-5957.2005.00049.x

10. G. Panne, Journal of Evolutionary Economics 14(5), 593-604 (2004) doi:10.1007/s00191-004-0232-x

11. T.I. Volkova, I.A. Usoltsev, The economy of the region 13(1), 290-307 (2017) doi 10.17059/2017-1-26

12. P.M. Romer, The Journal of Political Economy 98(5.2), 71-102 (1990) DOI: 10.3386/w3210 